\title{
IN THE SHADOW OF MOSCOW: THE STALINIST RECONSTRUCTION OF THE CAPITALS OF THE SOVIET REPUBLICS
}

\author{
Rasa ČEPAITIENE் \\ Lithuanian Institute of History, Department of the $20^{\text {th }}$ Century History, \\ Kražiu g. 5, LT-01108 Vilnius, Lithuania \\ E-mail: rasa.cepaitiene@if.vu.lt
}

Received 13 November 2014; accepted 13 March 2015

\begin{abstract}
Looking through the prism of USSR national policy the article analyzes the reconstruction of Stalinist cities. The study is based on the visual analysis of the city landscapes of the capitals of 12 of 15 former Soviet republics. Focusing attention on the mechanisms and tools of the formation of the capitals of the Soviet republics, the strategies and tactics of the reconstructions carried out in these cities are discussed. As their result in the late period of Stalinist culture the creation of an ideological-visual narrative of a major Soviet city, consisting of a united "content of socialist realism" and local "national forms", was completed. The conclusion is made is that mainly using plant and geometric ornaments of local folk art in the decor of the buildings of the socialist realism style, these capitals were "marked" in a specific way. However, although this aesthetic program allowed one to distinguish visibly these cities from one another, and to highlight some of the features of national cultures, however, the fostering of such narrowly understood and apolitical "folk character" at the same time restricted the possibilities of the Soviet connected nations to keep the abilities to preserve free and uncontrolled authentic expression of their cultures.
\end{abstract}

Keywords: "Stalin's Empire style", socialist realism, totalitarian architecture, "socialist content", "national form", capitals of the union republics.

\section{Introduction}

Although the post-Soviet development of the former USSR union republics - now independent countries over the last more than twenty years, both politically and economically, as well as culturally, were quite different, but they all had to deal with the problems of the evaluation of the Soviet period and the utilization of its tangible legacy in relation with the newly being created national identity. As is known, the Soviet modernization in a country having a huge territory and more than a hundred different nations living in it, sought not only to create a new type of society and to catch up with the industrialized Western countries, but also to level the enormous cultural and economic differences within the country for all the Soviet people by creating a unified cultural, world view and socioeconomic standard of living.

In these processes both in the Stalinist period, and afterwards a special role was provided for architectu- re. Until 1955 in the officially advocated doctrine of "socialist realism" the efforts of the totalitarian regime to create a unified and coherent aesthetic program that was to harmonize Sovietization with the declared promise of the "prosperity of the Soviet nations" were most revealed. What elements and signs of this program remain in the urban landscape of the capitals of the post-Soviet states and what do they mean today?

The ideological basics of the totalitarian regime - Marxism-Leninism and Soviet cultural policy (Bolshevik Culture 1985; Gill 2011), as also its integral part - the Stalinist regulations of city planning and the creation of architecture - have already attracted the attention of many researchers (Golomstock 1991; Papernyi 1996; Ivanov 2001; Khmelnickyi 2006, 2007). However, mainly focusing on the decisions taken in Moscow (Schlögel 2008) and the analysis of the forms of architectural expression spread from it there is still 
a lack of comparative works, covering not only the vertical "Center-periphery" relations, but also a comparative study of the horizontal processes taken place in different republics, in places seeking both commonalities and unavoidable differences.

Taking this into account later in the article, looking through the prism of USSR national policy, the trends of Stalinist urban and architectural development will be presented in the "national border areas" - the capitals of the Soviet republics. I will try to discuss the following questions:

1) what were the essential components of the theory and practice of socialist realism in architecture and urban development and how were they manifested in the contexts of different national cultures?

2) were there any qualitative differences between the pre-war and post-war reconstructions of cities?

3) which - Soviet, national or mixed - elements remained rooted in the landscapes of the capitals of the Soviet republics after their Stalinist reconstructions were completed?

4) is it possible in "Stalin's Empire style" to detect its local peculiarities and variations, allowing one to actualize it as part of the cultural heritage of the now independent post-Soviet states?

On the basis of the analysis of the visual patterns of most of the capitals of the former Soviet republics I will seek to show what specific forms the doctrine of socialist realism acquired in the periphery of the USSR and what the national policy of the USSR did they reflect. In this case, it is especially important to define and assess the scales of the ideologically motivated expression "of national form" and the quality of the local examples of the architecture of socialist realism. Seeking to measure in place the objects of architecture remaining from the Stalinist period and to find out how this architecture is evaluated today the capitals of twelve of the fifteen former Soviet republics were visited and studied - they are Moscow, Kyiv, Kharkov (the former capital of the Ukrainian SSR until 1934), the capital of the Belorussian SSR Minsk, the capital of Moldovian SSR Chisinau, the capitals of the Baltic states, Vilnius, Riga and Tallinn, the capitals of the Trans-Caucasian republics of Georgia, Azerbaijan and Armenia Tbilisi, Baku and Yerevan and the capital of the Turkmen SSR Ashgabat.

As one knows, the so-called "Stalin Empire style" or neo-classicism in the architecture of the USSR experienced even two waves of rejection: after the decisions of the party in 1955 "For the removal of excesses in architecture" and after the collapse of the very USSR, when buildings of this style were considered to be a symbol of all Soviet ideology and especially of its most hated period - Stalinism - were begun to be despised and were not considered to be a part of cultural heritage nor of the architectural history of the post-Soviet states (one can say this especially about the Baltic states). The most striking element of the decoration of the buildings of this style - Soviet symbols, which in the earlier post-Soviet period were removed from many of these buildings in particular, got hit. Such a "double" repression of this style, one has to admit, even today makes the investigation of this phenomenon more difficult, because, in addition to other reasons, determining the reluctance to take an interest in these objects in the former Soviet republics, there is another specific obstacle: some of the still living creators of this style are reluctant to admit they had contributed to the design and realization of such works, what limits the search for primary sources.

\section{The creation of a new ideological landscape}

The American researcher A. Tung, presenting the broad panorama of the preservation of the historical cities, also partially touched the problem - why virtually for all of the totalitarian regimes of the first part - middle of the 20th c. in Europe (and remembering the case of Maoist China, not only in Europe) one needed to transform fundamentally in this way their capitals and other major cities (Tung 2001)? It is interesting that almost all the leaders of the totalitarian states in the first half of the 20th c. - A. Hitler, B. Mussolini (Golomstock 1991), later - N. Ceaușescu, etc., up to the current authoritarian presidents of the natural resource-rich post-Soviet Central Asian states of Kazakhstan and Turkmenistan, who also recently begun the grandiose reconstruction of their national capitals, undertook gigantic architectural projects and at the same admitted "love for the classics". As one knows, the capital of Kazakhstan was moved in 1997 from Almaty to reconstructed city Astana (formerly - Aqmola, in the Soviet era - Celinograd. By the way, astana in the Kazakh language means "capital") (Anacker 2004). In turn, the total reconstruction of the Turkmen capital of Ashgabat begun under the rule of President Saparmurat Niyazov Turkmenbashy (1991-2007) according to the plan management should be completed by 2030 .

The streams of rationalism, futurism, realism and functionalism soaring in the architectural theory at the beginning of the 20th c., despite certain differences between the East and the West, preached simplicity and the hegemony of the mechanical world (Choay 1998). While being oriented to the narrowly understood human functions and needs, such a modern architecture had to subordinate man for society's needs, and that was also close to totalitarian thinking. The "progressives", to 
whom we also assign the early Soviet urban plannersconstructivists M. Ginsburg, J. Kuzmin, M. Milyutin who designed the "socialist city" et al., created functional cities, tailored to the needs of industrialization. They thought that urban structures are required to become a spatial expression of the socio-political system. The revolutionary euphoria of the Bolsheviks in Russia was expressed especially in gigantic industrial constructions that became symbols of the carried out system of forced modernization, embracing the large industrial complexes and the experimental "socialist cities" (Meerovich et al. 2011). Such model proletarian culture was being created in Magnitogorsk, Komsomolsk on Amur, Novokuznetsk (Stalinsk), Karaganda, and so on, although the radical transformations in one form or another touched all the cities of the country. According to the data of the 1939 census, over twelve years (since 1926) the urban population of the Soviet Union increased from 26.3 million to 55.9 million (Kotkin 1995: 18). Even including the post-revoliutionary redistribution of the social layers of the population, this was probably at that time the largest jump of urbanization in the world during a decade (Rashin 1960; Andreev et al. 1990; Yusupov 1992). One should keep in mind that the prisoners of the Gulag were also classified as "city residents". In this way, the total socio-economic transformation carried out in the USSR embodied the scientific and technological achievements using the ideals of the Enlightenment to create a society of a new type.

Social relations of the new type and the self-consciousness of the population, willingly prepared to sacrifice for the defense of the collective Soviet homeland against numerous external and internal enemies in the name of its economic flourishing, had to appear in the socialist cities. So one can say that the construction and reconstruction of Soviet cities were at the same time the means and goal of the Communist revolution. The totalitarian system sought to create it as a powerful military-industrial complex able to protect it from the potential interventions of external enemies, by expanding the networks of the repressive apparatus within the country, and, what is no less important, starting the very active and aggressive indoctrination of society. According to Mark Meerovich, who researched early Stalinist construction policies, such priorities of the government, although also always masked, had very significant practical effects - throughout the whole Soviet period there was a constant lack of living space in the country. What is more, in his opinion, taking advantage of the monopolized right of the government to real estate, this was a fully conscious and highly effective way to connect, control and manage the masses of population (Meerovich 2008).
In post-revolutionary Russia a new culture was spontaneously formed, the so-called Proletarian cult (Proletkult), a dynamic, active stream of proletarian culture, breaking norms and traditions, a movement of avant-garde, folk art, not regarding and rejecting the legacy of earlier eras. The architecture and arts of that time were also guided by avanguard, modernist concepts, in architecture the internationally well-evaluated constructivism won high positions. However, entrenched at the peak of political power around 1927-1932, Joseph Stalin chose a completely different aesthetic program - the so-called socialist realism (Cooke 1993; Dobrenko 2007) -and forced Soviet architects and artists to reorient themselves to it rapidly. More traditional and coarser realism began to replace the experimental and modernist art of the times of the revolution from around 1927, entrenched in 1932 in the form of the method of socialist realism, which had become a mandatory doctrine for everyone. According to one of the most prominent researchers of this architectural style V. Papernyi the turn of the 1930s toward socialist realism in architecture and urbanism reflected the changing social organization in the direction of totalitarianism and marked the consolidation and hierarchy of political power (Papernyi 1996).

In Soviet cities first of all there was an effort to implant a certain unified ideological scheme (Milerius 2008; Gill 2011), regardless of localized differences everywhere forming a coherent visual narrative. For this such subjects as Lenin, the October Revolution, "the leading role of the Party", "the government of the people", later - "Victory in the Great Patriotic War", etc. were deployed. Therefore, in public, especially representative spaces, monoperspective, one-dimensional, inflexible, value-united "knots of symbols", which had to hand over to the visitor or resident of the city simple, unambiguous ideological messages extracted with the help of well-thought-out visual, aesthetic, technical, discoursive and other means were reinforced. In the representative squares of the city the whole ideologically colored complex of objects and toponyms was used - the visual emphasis (public monument), names of streets, the surroundings of official buildings, etc.

The typical subjects of communist ideology in specific landscapes of cities had to meet the work of not only legitimizing the new government, but also the synchronization of the ideologically approved version of the unified past (Milerius 2008), allowing, in spite of the individual differences in the history of a specific nation or city, "to read" them everywhere as essentially an identical text. For example, in almost all the larger or smaller cities Lenin Squares with a monument of the leader appeared in its center (Fig. 1), 


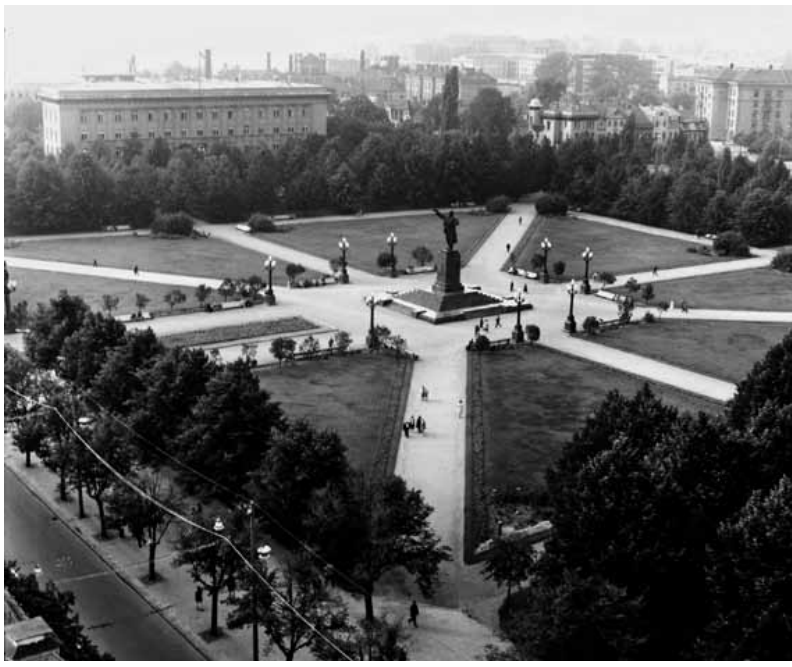

Fig. 1. Lenin (now Lukiškès) Square in Vilnius 1972. A. Brazaitis photo. Lithuanian Central State Archive 1-20202

streets of his name, museums, etc. Other Communist figures and heroes of labor and war also received similar public honor, only on a smaller scale, respectively. Central public spaces also served for mass events rallies, demonstrations, parades.

Another extremely important plot of "the great Soviet narrative", the visual traces of which we will find in many capitals of the Soviet republics - "Victory in the Great Patriotic War". One has to note that after the war some cities even were awarded a special "cityhero" status. Already in the post-Stalinist period, in the 1960s-1980s in addition to other cities Moscow, Kyiv, Volgograd (at that time Stalingrad) and Minsk even re-

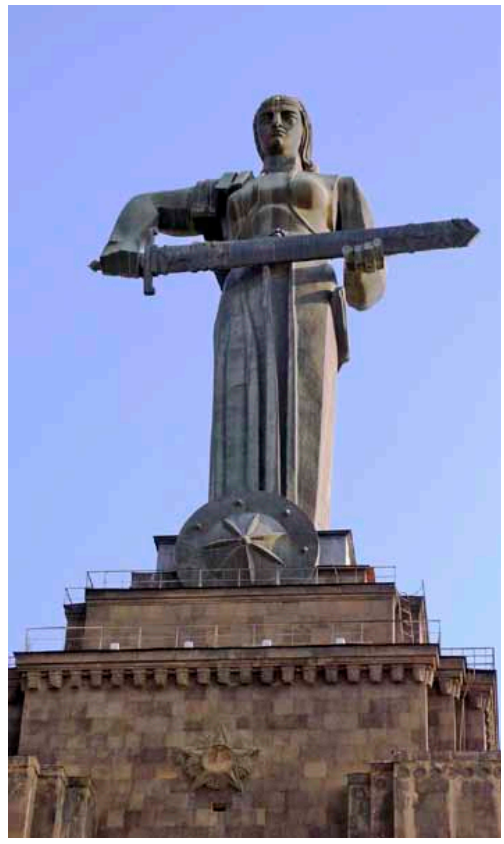

Fig. 2. "Mother Armenia" monument in Yerevan. R. Čepaitienè photo ceived this status. Although the monuments becoming formants of the Great Patriotic War in the ideological spaces of the capitals of the Soviet republics and other cities were built at different times, usually already after the death of Stalin, characteristic for all of them are namely the socialist realist aesthetic expression formed in the Stalinist era. The following objects are worth mentioning: the memorial of Mamaev Kurgan with the world's largest at that time monument "MotherHomeland Calls" in Stalingrad (1959-1967, sculptor E. Vuchetich), "Mother Armenia" in Yerevan (pedestal in 1950, statue in 1967, sculptor A. Harutyunyan, erected after the removal of the monument to Stalin that stood there earlier) (Fig. 2), "Mother Georgia" in Tbilisi (1958, sculptor. E. Amashukeli), monument of Victory in Kyiv, Ukraine (1981, sculptor E. Vuchetich and others) (Fig. 3), etc. The similar project in Vilnius for the planned Victory monument on Mount Tauras remained unrealized (Drèmaite 2009).

It is interesting that in the cultural memory of Belarus it, no doubt, up to now fundamental remains the collective narrative. In the landscape of the city of Minsk the Victory Square and the $38 \mathrm{~m}$ high obelisk adorned with 4 impressive reliefs, the Belarusian national ribbons of ornaments and the Victory Order at its top (in 1950-1956, architects G. Zaborski and V. Korol, sculptors Z. Azgur, A. Bembel, A. Glebov and S. Selikhanov ) (Fig. 4) testify to this. Meanwhile, in Vilnius the memory of World War II was embodied in the tomb of General I. Cherniakhovsky and his monument (1950 sculptor N. Tomsky), the group of the sol-

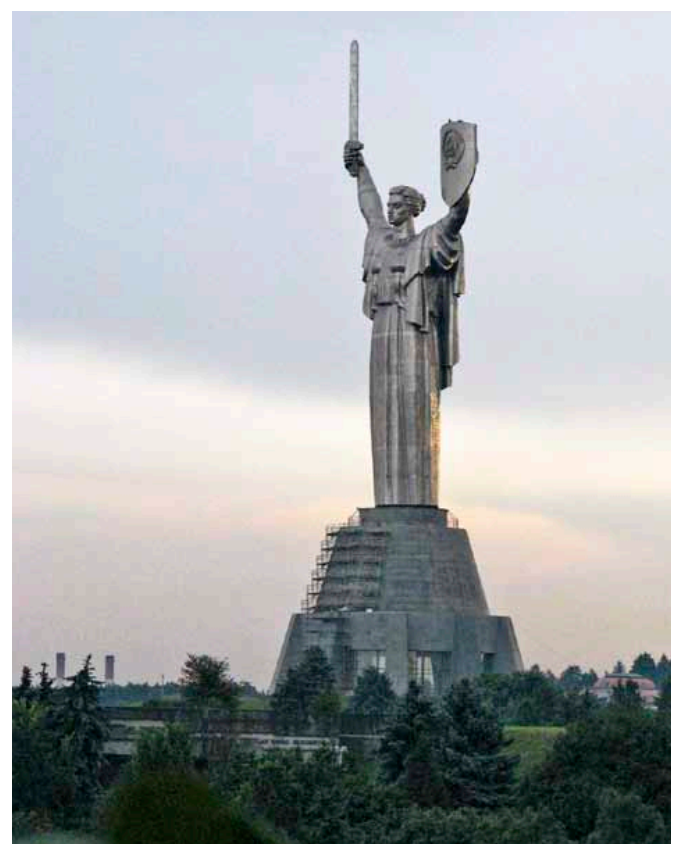

Fig. 3. Victory monument in Kyiv, Ukraine. R. Čepaitienè photo 
diers-liberators of the Green Bridge (B. Pundzius "On guard for Peace", 1952) (Fig. 5), and the later memorial to the soldiers of the Soviet Army in the Antakalnis cemetery (1982) with an eternal flame and the monument in the Pylimo street square "To Soviet partisans and members of the underground" (1983, sculptors J. Kalinauskas and A. Zokaitis, arch. G. Baravykas, K. Pempe, G. Ramunis) built after the destruction in that place of the former community cemetery and chapel of the Calvinists.

The grandeur of the representational spaces of the imperial USSR capital Moscow (Clark 2011) and the other largest cities had to embody visually the durability and longevity of the Soviet system. The impressive and monumental examples of social realistic architecture, presented to the observer and inhabitant of the cities, also served the function of an effective means of visual propaganda. The architecture of the Stalinist regime became the ideal model, embodying the future society of surplus. In the totalitarian sociopolitical framework official architecture carried out the function of "stage decorations" (Abensour 1997) for mass rituals - parades, demonstrations and rallies -, facilitating the process of the deindividualization of society and at the same time the process of the neutralization of rational thinking and a critical relation with the regime. Furthermore, it became the material illustration and the embodiment of dreams (Čepaitienè 2011) for the constantly postponed promises to the Soviet citizens to create at least endurable living conditions, which in reality only members of the state apparatus or citizens absolutely loyal to the regime could use. The grandeur, impressiveness, smartness and the massiveness of the broad avenues, bright streets, public spaces and buildings at the same ideology also expressed claims on eternity.

In turn, the abundant and frequent citing of references to the "classical legacy" in the buildings of this style gave them credibility and a relationship with the world's cultural heritage. However, it is quite difficult to define the theoretical foundations of Stalinist architecture that began to be formed in the 1930s. On the whole it would be difficult to speak about any coherent theory; this probably was a certain collection of stylistic measures and images (Papernyi 1996). However, a rigorous ideological selection was applied in regard "to the legacy of the past": it was not allowed to use the styles of Gothic and modern as "the times of social downturn", Baroque was undesirable, Western functionalism and local constructivism were flatly rejected (Khmelnickyi 2007). One had to use only elements of classical architecture, taken over from ancient Greece and Rome, the Italian Renaissance, the Russian Empire style. National republics were still allowed to restrictedly use elements of local historical styles. The latter provision grew out from the then national policy of the USSR, which one should briefly discuss further.

\section{The formation of the capitals of the Soviet republics as a reflection of USSR national policy}

The pre-war foreign policy of the Soviet Union reveals that Joseph Stalin essentially sought to restore the former borders of the tsarist empire. Except for the failed attempt to reincorporate Finland in the Winter

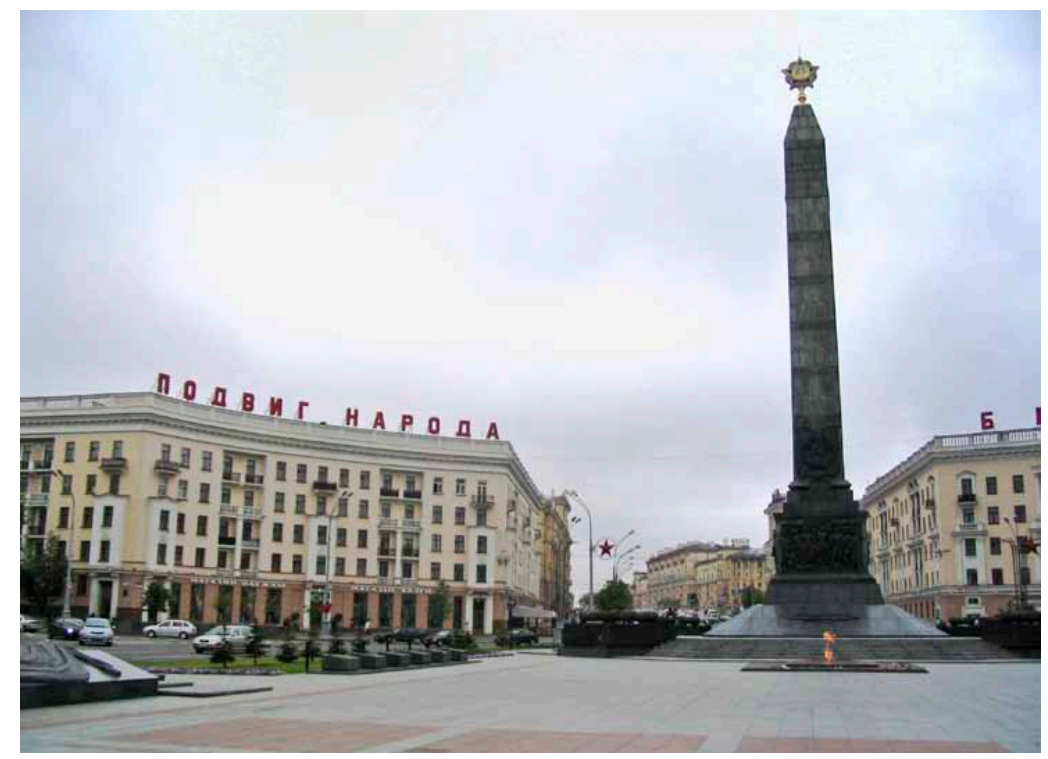

Fig. 4. Victory obelisk in Minsk, Belarus. R. Čepaitienè photo

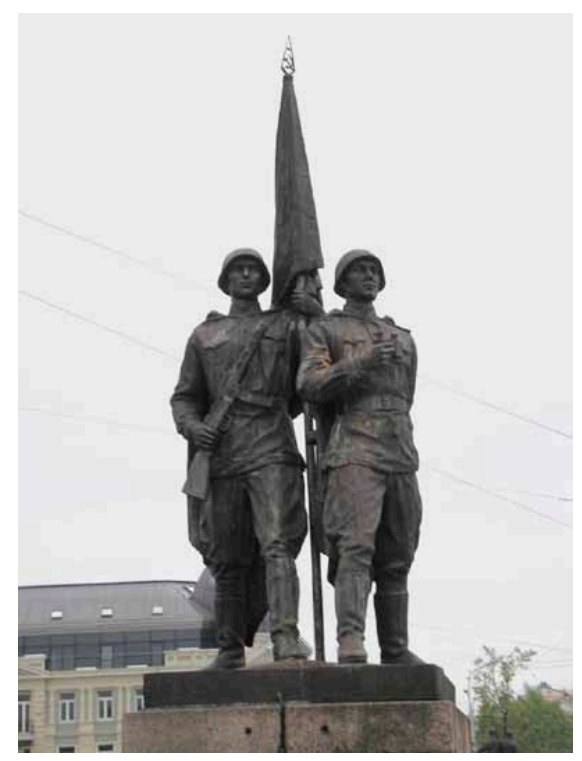

Fig. 5. Green Bridge sculptures in Vilnius, Lithuania. R. Čepaitienè photo 
War of 1939-1940, to a great extent he succeeded in achieving this, in 1940 connecting not only the independent Baltic states, but also Bessarabia.

The Soviet Union was essentially formed as a multi-national union state, made up of Soviet republics (in 1945-1956 there were 16, including the KarelianFinnish SSR, which was later transformed into an autonomous republic, later - 15), in the composition of which (mainly in the RSFSR) there were 20 autonomous republics, 8 autonomous areas oblasts and 10 autonomous districts. All of them were created on a national basis. In the USSR there lived people of more than 100 nationalities, most of them - Slavs, among whom the Russians dominated. However, all the major Soviet administrative structures were named according to the name of the nation living most abundantly in the territory, except for Kazakhstan and Kyrgyzstan, where the Kazakhs and Kyrgyz respectively comprised only about 36 and 41 percent of the local population and in many of the autonomous formations - even less. Ethnically Armenia (more than 90 per cent) was the most monolithic, and the Russians, Belarusians, Azerbaijanis and Lithuanians comprised more than 80 percent of the population of their national republics.

The model of Soviet statehood was marked by particular features, in a paradoxical way coordinating imperial and federal provisions, forced Sovietization, Great Russian chauvinism and the ideological postulate of the "friendship of nations". The national policy of the USSR was really specific. Speaking about its origins, one must take into account the campaign of koreanization (korenizatsiya in Russian, meaning "nativization" or "indigenization", literally "putting down roots") widely pursued during the first decades of the formation of the Soviet system, which exactly sought to distance itself from the regulations of the tsarist ancien régime in regard to national minorities (Cadiot 2007), making the local cultures privileged. In the detailed work of Terry Martin devoted to the latter topic (Martin 2001), one can note that in the Soviet Union, as the first empire of this kind, the titular ethnic groups of the individual administrative regions, despite the common Soviet ideological indoctrination and the aspiration to create a homo Sovieticus who had lost national characteristics, was consolidated in particular on a national basis and even supplied with certain state and cultural institutions. In case of need their own alphabets and press were created, the structure of national managerial personnel was formed; a network of cultural and educational institutions was financed and promoted. For these activities the national intelligentsia received significant government support. True, these processes did not last and Sovietization covered by the open Russification of the national minorities, perhaps breaching the most the national consciousness of such nations as the Kazakhs and Belarusians, and the majority of the representatives of the elites of the "national borderlands" that had easily having taken over the Russian language and culture, eventually replaced the koreanization.

According to national Soviet policies the administrative centers of the union republics had to carry not only the most important socio-economic burden of the region, but also become the symbolic capitals of the union or autonomous republics. Symbolic, because they could not carry out the real role of a representative of statehood, for understandable reasons the sovereignty of the republics was only formal. It is worth emphasizing that the cities of the national borderlands of the USSR selected for this purpose, had very different backgrounds and not equal valued history. Some of them, such as Kyiv (historic center of medieval Kievan Rus'), Kazan (the capital of Tatarstan), and the capitals of the Trans-Caucasian and Baltic states, had already been the centers of national statehood, while others were deliberately selected and restructured in order to acquire the status of the symbolic capital of the titular nation of a specific republic, such as for example the new capital city Chisinau of Moldova, which in 1918-1940 was in the composition of Romania.

The processes of the "invention" of capitals particularly affected the five new union republics of Central Asia, which were created in 1924, subdividing autonomous republic of Turkestan being the part of the Russian Federation. These processes did not always go smoothly; there were cases when the status of the capital city had to be given to another town than was originally envisaged. For instance, in 1934 the capital of the Ukrainian SSR was returned from Kharkov to Kyiv, the capital of the Uzbek SSR was moved from Samarkand to Tashkent, and the capital of Turkmenistan was moved from the northern Cherzhou to the south, to Ashgabat on the border of Iran.

While the adopted in 1935 project for the reconstruction of Moscow became the standard and the role model of the urban changes of USSR cities, but studies would show that, despite the widespread in the whole territory of the USSR and easily recognizable buildings of the "Stalin's Empire style", neo-classicism acquired distinctive features in the form of the capitals and other largest cities of the Soviet republics. This was both a reflection of the expectations of local construction specialists and the ideological declaration to promote the testimony of local cultures as well as the trend, lowered and promoted directly "from the Center". 
Specialists from Moscow, Leningrad and the other largest cities of the USSR were often sent to develop and implement the reconstruction plans for the capitals of the union republics. These architects and urban planners, except in certain cases, usually were not more deeply familiar with the history and cultural specificity of the local architecture. Probably the most notable exceptions - the post-war reconstruction in Chisinau led by a representative of the highest elite of the USSR architects, born in this city Alexey Shchusev, while in 1924 the general plan of Yerevan was developed by the returned to his homeland from Moscow the famous Armenian architect Alexander Tamanyan. However, in other cases, the creations of the arriving architects usually had little to do with the genius loci of the reconstructed capitals. Therefore, their attempts also to synthesize classic and local folk art forms were not always successful, and were limited only to the formal use of elements of local folk art in the decorations of buildings (this is especially apparent in Vilnius, Riga and Tallinn). In addition, their creativity was also limited by the ideological pressure not to deviate from the narrow party lines in the direction of the unauthorized rehabilitation of the "culture of the bourgeois past". Perhaps the capitals of the TransCaucasus and the Central Asian republics should be regarded as the most successful cases of "koreanization in architecture" (Fig. 6).

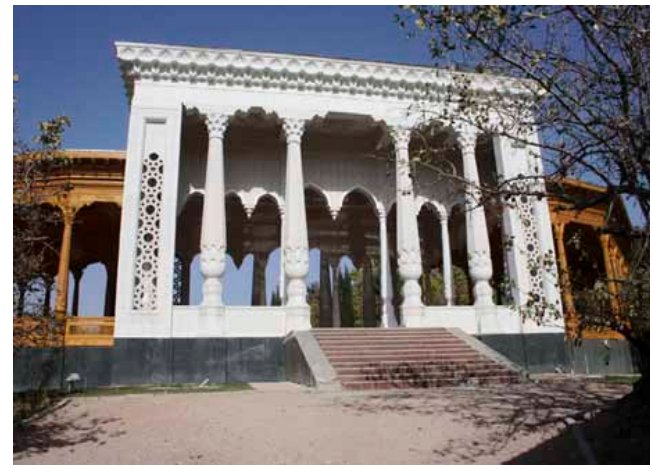

Fig. 6. The central entrance to the Recreation park. Dushanbe, Tadjikistan. A. Isserov photo

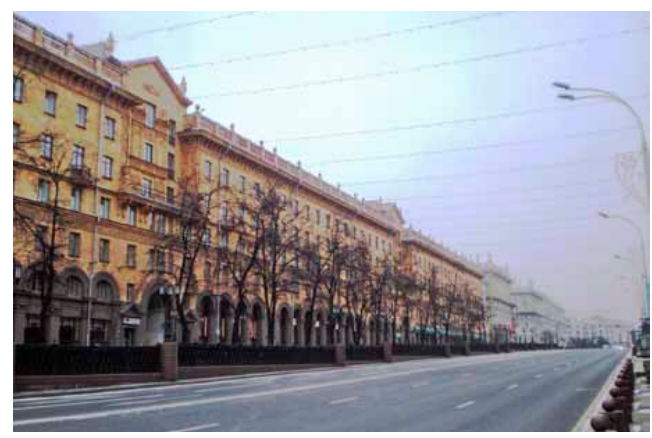

Fig. 7. The former Lenin Prospect in Minsk. R. Čepaitiene photo
Speaking about the scales and measures of the transformation of the capitals of the USSR republics one needs to pay attention to the historical context, explaining the diversity of the completed urban reconstructions. For example, the capitals of the Central Asian republics were architecturally formed mostly in the pre-war period. Meanwhile, part of the capitals of the union republics were more or less sovietized already after the Second World War as a consequence of "the liquidation of the mass demolitions". The territories occupied by the Nazis during the war fall into this group. However, the scales of the change of the capitals of the western USSR republics were also quite different. For example, the capital of the Belarusian SSR Minsk, in which before the war significant for the transition period and neoclassical buildings were built, after the war was finally converted into a "model Soviet city" (Fig. 7). Meanwhile, in other cities this was mainly confined to the central avenues: such as the reconstruction of the famous Kreshchatyk of Kyiv (Figs 8, 9) or the Lenin Prospect in Chisinau (now - Stefan cel Mare) (Fig. 10), the installation of symbols of the regime (the Stalin skyscraper in Riga (1952-1958)), or the visual sovietization of the main squares of a city (Lenin (now Lukiškių) Square in Vilnius). Most importantly, despite the planned significantly more massive restructuring of the Baltic

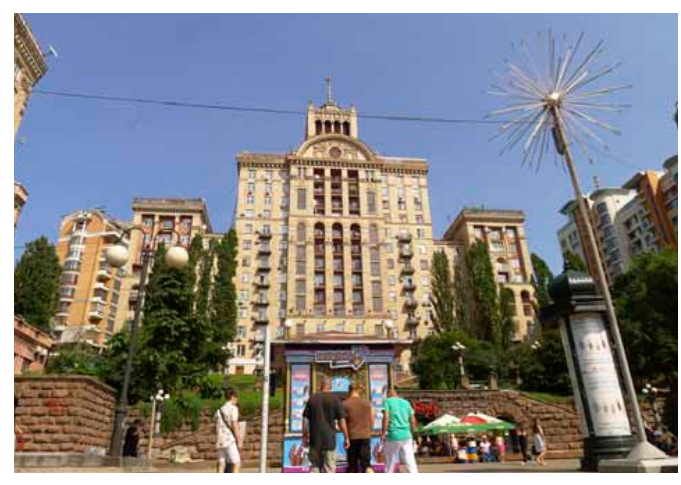

Fig. 8. The architecture of the Kyiv Kreshchiatik. R. Čepaitienè photo

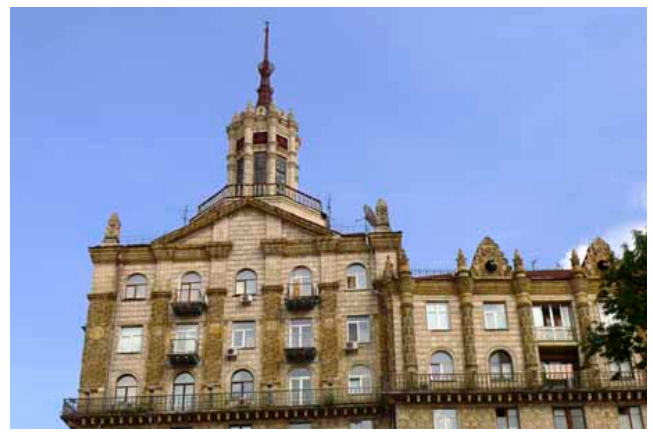

Fig. 9. The architecture of the Kyiv Kreshchiatik. R. Čepaitienè photo 
capitals (Bogdanov 1950), just as in Tbilisi and Baku, one managed to save the valuable historic old towns. On the other hand, it is possible to distinguish a group of capitals, which were rebuilt several times not due to the destructions of war, but due to natural cataclysms: these are Ashgabat after the earthquake in 1948, Tashkent after the earthquake in 1966, etc.

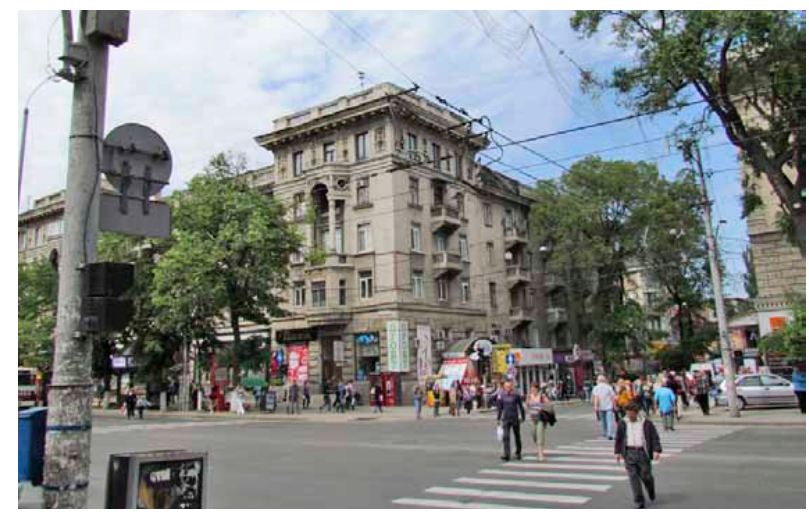

Fig. 10. Former Lenin Prospect in Chisinau, Moldova. R. Čepaitienè photo

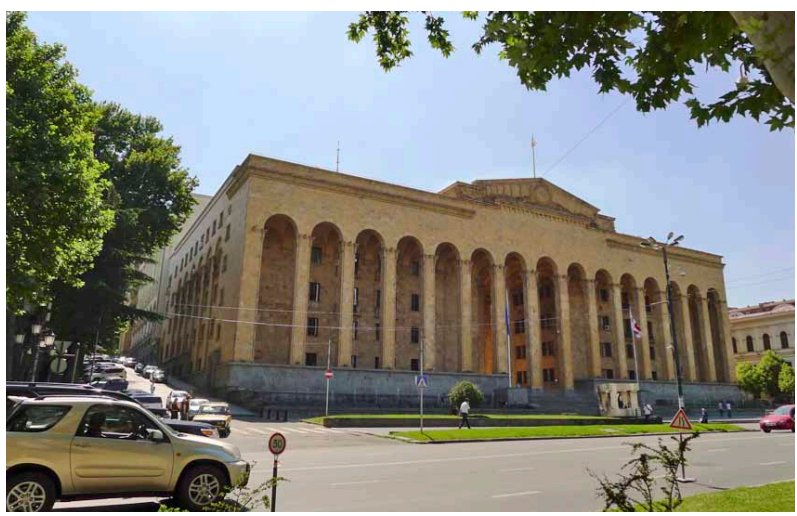

Fig. 11. Former palace of the Georgian SSR Supreme Council. Tbilisi, Georgia. R. Čepaitienè photo

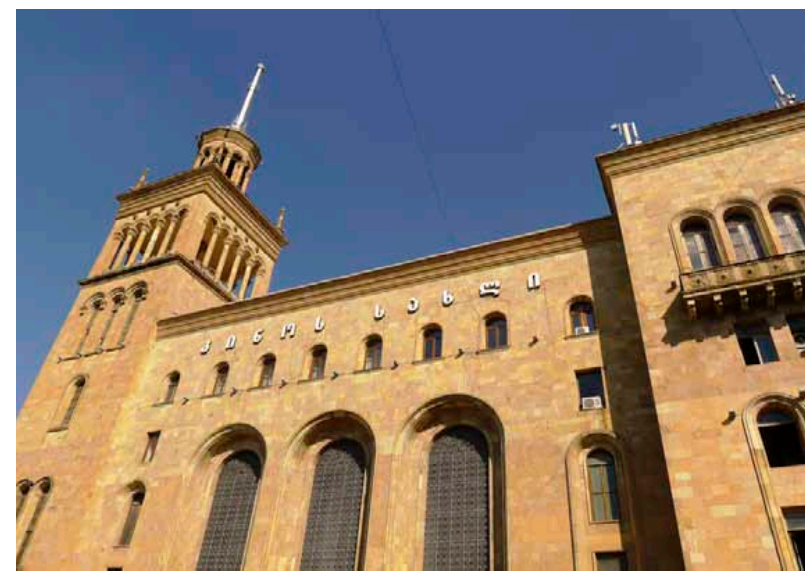

Fig. 12. Palace of the Academy of Sciences. Tbilisi, Georgia. R. Čepaitienè photo
So basically the shape of the capitals of the Soviet republics was sovietised on a different scale and time.

The cities of Central Asian also developed further on the basis of the colonial legacy of the Russian Empire, for which a system of city-doubles is characteristic (Kosenkova 2010), dividing the city into European and Asiatic parts (Tashkent, Fergana, Andijon), or only had an European part, such as Almaty (the former fortress Verny), Ashgabat (in 1919-1927 Poltoratsk), etc. Because classical European architecture could for the residents of the Trans-Caucasian and Central Asian republics continue to be associated with the former practices of colonialism, Soviet urban planners here began to use actively the newly re-interpreted and adapted historically formed local architectural traditions and forms. As a conseuence of this a rather paradoxical situation developed when the "national form" of the socialist realist architecture in these republics began to be based on the constructive solutions and aesthetic forms of medieval Christian sacred, such as in Georgia and Armenia, or Islamic (Azerbaijan and the Central Asian Republics) architecture. They were allowed to continue local building traditions using local building materials - mountain rock (in the capitals of the Trans-Caucasian republics). This provided these cities with an exceptional distinctive character, for which Yerevan and some other buildings of the capitals of the Trans-Caucasian republics are especially characterized, for example, the Palace of the Supreme Council and House of Government (1938, architects V. Kokorin and G. Lezhava) (Fig. 11) and the building of the Academy of Sciences in Tbilisi (1953, architects M. Chkhikvadze and K. Chkheidze) (Fig. 12) or the Palace of the Council of Ministers in Baku (1936-1952, architects L. Rudnev, V. Munz) (Fig. 13).

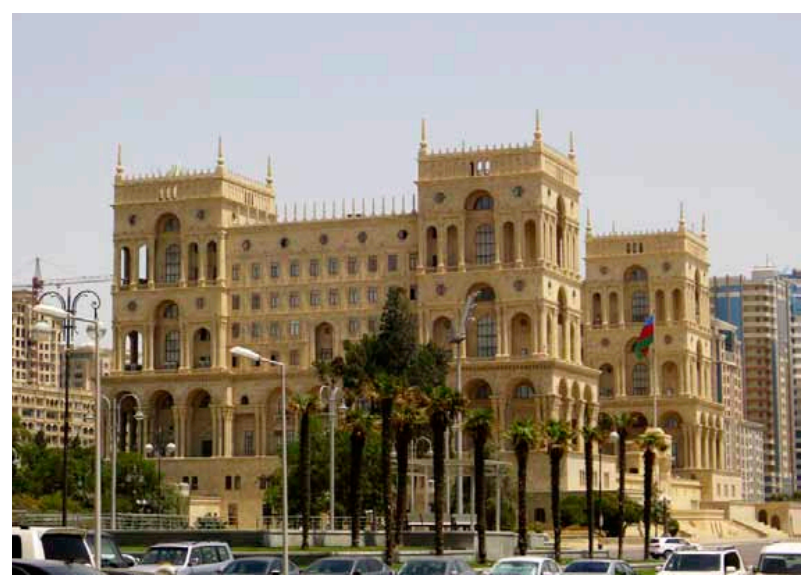

Fig. 13. Palace of the Azerbaijan SSR Government. Baku, Azerbaijzan. R. Čepaitienè photo 


\section{Minsk and Yerevan - different directions of reconstruction}

Speaking about the most significant examples of Stalinist architecture in Soviet national peripheries one can remember not only the unrealized Palace of the Soviets or the ring of seven skyscrapers encircling the center of Moscow (Vasykin, Nazarenko 2009), but also the great prospects and buildings in the largest cities of the USSR or even beyond its borders, such as Warsaw's Palace of Culture and Science or the Stalinist skyscraper in Riga. However, it is still the accumulation of individual urban structures or architectural objects, rather than the completed and embodying totalitarian logic text of the city. In the opinion of some researchers, only the Belarusian SSR capital Minsk managed to approach the ideal totalitarian city.

What makes this city so special and aesthetically pleasing even today, despite the uncompleted destruction in Soviet times of fragments of the old blocks or the post-Soviet development in the suburbs? Why were such large financial, production and human resources cast in the postwar reconstruction of this city, allowing to create its exclusive shape? At least a few assumptions can be drawn. First of all, the Belarusian nation in Soviet national politics came into the group of "fraternal Slavic nations", which, together with the leading Russian and Ukrainian nations, formed an exclusive and a kind of privileged group. On the other hand, the Sovietization of Belarusian society, even in comparison with the other mentioned Slavic nations took place more smoothly precisely because of the lack of strong historical consciousness. Belarusian culturologist Julia Cherniavskaya has analyzed the question of why Belarusian society so surprisingly welcomed the Soviet government, and eventually organically accepted it as its own? Since Belarusians had also previously been in the orbit of Russian culture and government, the Bolshevik revolution in 1917 and the radical social changes that occurred in its aftermath did not become as painful as the events of 1940 in Lithuania, Estonia or Moldova. On the other hand, the new ideology somehow coincided with the normal, traditional prevailing worldview of the Belarusians: the historic change of "foreign" governments, as well as the rooted in Belarusian society social idea, subordinating the national ("the rich and evil foreign gentleman" and "the poor and good peasant" (= Belarusian)), the value of land and work with the land, the multiculturalism characteristic of the cities and towns of Belarus, the ordinary culture of scarcity as well from its consequent sense of egalitarianism and social conformism - "the unwillingness to jump out", as well as the relatively weak religiosi- ty - all these elements of the specifics of Belarus became the principal bases for the smooth consolidation of Soviet power in the country (Cherniavskaya 2010; Cherniavskaya 2011).

Unlike the capitals of the Baltic states, for which, for obvious reasons, the largest "weight" of Sovietization falls to the post-war period, because during the first Soviet occupation in 1940-1941 they simply did not have time to do anything more important, Minsk already in the period between the wars had been formed as the capital of the Belorussian SSR (Prot'ko 2002). The most significant objects built in Minsk at this time - the Government House (in 1930-1934, architect I. Langbard), the Palace of the Academy of Sciences (in 1932-1939, architects G. Lavrov and I. Langbard), Opera and Ballet Theatre (in 1934-1938, architect I. Langbard) (Fig. 14) and others - stylistically belong to the transition period from constructivism to the "Stalin's Empire style" or postconstructivism. Ala Shamruk, who investigated the development of the architecture of Belarus in the 20th c., is inclined to regard it as an independent phenomenon, mostly manifested in 1934-1941, which is characterized as the stylistic synthesis of constructivism, neo-classicism and art deco, "plugging up" the "corners" of the opposing currents (Shamruk 2007).

The excuse to restructure the capital of the Belorussian SSR became the damages the war made on it. During the war more than 80 percent of the residential buildings of Minsk were destroyed, not to mention the social and industrial objects (Volozhinskyi 2007). The recovery works of the urban infrastructure here, as well as in neighboring Vilnius, took many years. But perhaps the most important precondition for the different strategies of the urban restructuring of the "Soviet capitals" in Vilnius and Minsk became that in them were basically realized conceptions of the Soviet

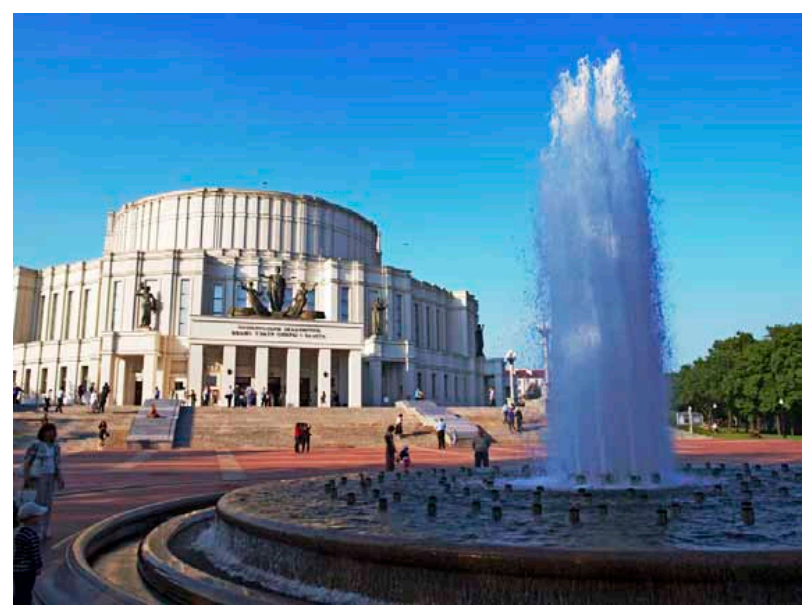

Fig. 14. Palace of the Opera ir Ballet Theater in Minsk. D. Mačiulis photo 
government seeking different goals not only in regard to these cities, but appropriately to the Lithuanian and Belarusian nations. In the first case, one needs to speak about the Lithuanianization of Vilnius returned to Lithuania by the Soviets in 1939 taking it from Poland, and in the second - the Sovietization of Minsk. According to historian T. Snyder, the post-war Soviet policy made concessions to the ethnic Lithuanian nation, but pushed similar Belarusian claims into oblivion (Snyder 2003). The Soviet authorities tried to undermine utterly the claims of the Belarusians to independent statehood and in exchange for the development of authentic modern culture imposing the model of Soviet modernization.

In the history of Minsk the years 1953-1959 can be considered as a turning point (Borovoy 2004), because at that time the vision of the total cleaning of the urban space for the new socialist city was selected and implemented. The pages of the album of archival photographs prepared by Vitaly Kirychenka are an eloquent testimony to this (Kirychenka 2006). Leaving only a few chaotically scattered inclusions of old historic Minsk, the city was turned into a three-dimensional illustration of a Soviet-style "welfare state" and the perfect "socialist city". Belarusian architect and artist Artur Klinov, having released Little Tour Guide around the Sun City (Klinov 2008) and the album Sun City (Klinov 2009) with a title borrowed from Tommaso Campanella links the transformation of Soviet Minsk to the ideas of the utopians of Modern times. In his books, playing with the meanings of the word sun (Bel. sonce) and dream, sleep (Bel. son), the author asserts that Minsk during its last reconstruction was deliberately designed as an ideal, utopian city. In reality, however, this dream has remained a mirage - the city became only a decoration of the sought ideal consisting of wonderful, but flat palaces, a city, in which there is one long street (Lenin, now Independence Prospect), which leads east to the real altar - Moscow. If Moscow was envisaged as the center of the utopia and there the ideal Soviet city had to appear, then Minsk was built as a triumphal arch, as a gateway to the center. But, paradoxically, not Moscow, but Minsk totally realized this Stalinist vision (by the way, the concept of the city as the "gateway to Rome" was known in urban development already from the times of antiquity, when in the centers of some colonies triumphal arches were built, designated for the Roman armies marching into Rome after winning victories. Oriented in the direction of Rome remain up to now, for example, the urban structure of Timgad (established by emperor Trajan in 100 BC in northern Africa, now Algeria)).
The nature of the illusory grandeur of Minsk can be easily unmasked by glancing at the courtyards of these abundant palaces designed for the people - a contrast with the Corinthian and Ionic orders adorning the ceremonial facades, the ornate cornices, the rich décor and monumental arches are just glaring. From the courtyard side the not plastered walls and poor balconies with billowing laundry leave the impression of a sufficiently poor household. The British researcher of visual culture Benjamin Cope has half-jokingly called the dominance of such hollow, illusionary architecture in Minsk ghostly classicism (Cope 2008).

Because in the scenario of the development of post-Soviet Belarus with the Soviet era continuity was maintained (Leggewie 2010), which would show, for example, both the Soviet names of streets and the abundance of monuments in the current fabric of the city, one can say that the forms of totalitarian architecture today are usefully exploited for the needs of the new authoritarian government. This hinders any kind of more active desovietization of the country and society (Galinovskaya 2008).

In contrast to Minsk, the large-scale reconstruction of Yerevan begun in 1924 according to a project of A. Tamanyan was based on a distinctive national style evolved from the centuries-old traditions of local stone splitting, mostly characteristic for church architecture, using the rocks of the local mountains - tuff and basalt of various shades. This allowed the creation of an exceptional and unique form of the capital of the Armenian SSR. According to Tamanyan's conception Yerevan had to become a kind of parquet and the road leading towards Ararat - the esteemed holy mountain of all Armenians (Fig. 15), and, despite some initial adjustments of the first project, this goal was largely achieved (Balyan 2010).

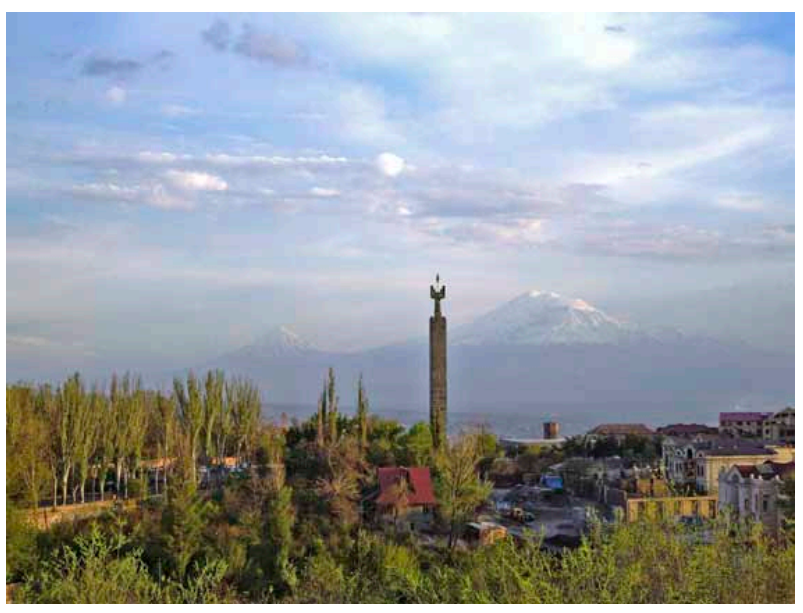

Fig. 15. Panorama of Yerevan with Ararat. A. Ayvazyan photo 


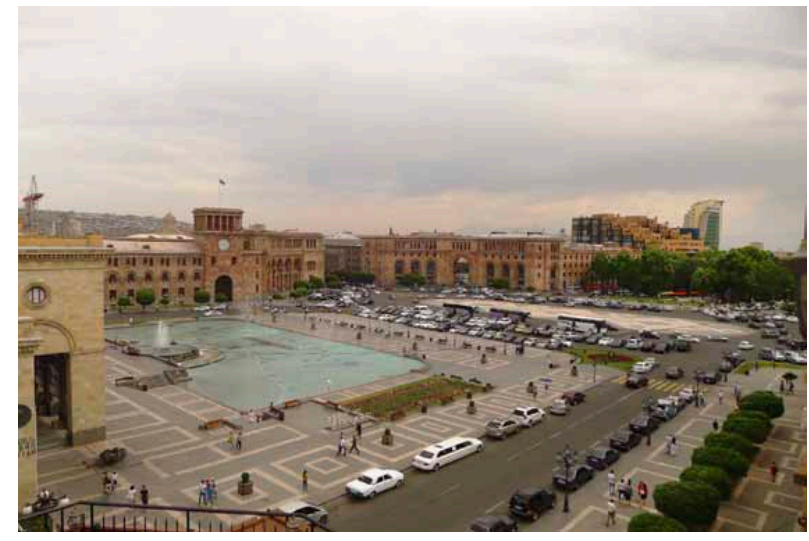

Fig. 16. Republic (formerly Lenin) Square in Yerevan. R. Čepaitienè photo

Although the case of Yerevan would show that sometimes talented architects succeeded in reconciling creatively the constructions, structures and decor of new buildings with the ideological requirements and local traditions of building (Fig. 16), by adapting local architectural, engineering and ergonomics decisions, but this, as mentioned, often balanced on ideologically permissible limits and at times created paradoxical meaningful effects. Therefore, in order to avoid the undesirable associations raised by Stalinist architecture with the sacred, "of the landlords" or "bourgeois" architecture, Soviet urban planners seeking to implement the required ideological postulate of "national form", often chose a less problematic and dangerous way - using folk ornamentation in the decoration of buildings. And although Soviet symbols - the hammer and sickle, a five-pointed star, insignias, shields, swords, flags, oak leaves, etc. essentially continued to dominate in this area (Alekseev 1954), eventually the decor of the exteriors and interiors of the socialist realist buildings became more diversified, including more and more elements of the traditional art of the USSR nations (Yaralov 1971).

\section{Searches for "national form"}

The Sovietization of the USSR urban landscape was carried out not only by the method of the abovementioned synchronization of the ideological narrative, in the words of Stalinist jargon, introducing a "socialist content", but also by highlighting those local cultural peculiarities, which allowed for better absorption of the Soviet metanarative in specific areas - the "national form". The latter was intended to reflect the peculiarities of the local art traditions of the USSR nations.

Researchers are still arguing, is the tendency to the exaggerated decoration of buildings and the tre- atment of national themes in the architectural details of the "Stalin's Empire style", in particular using the national ornament more characteristic of the second phase, or rather the "sunset" of Stalinist architecture (Golomstock 1991; Shamruk 2007). However, after glancing over many albums, in which the best examples of the socialist realist style are demonstrated, one forms the impression that before the Second World War, at least in Transcaucasia and several Central Asian Soviet republics actively using national art decorations, there were created quite a number of decorative buildings of very high artistic quality. They are, for example, the "Homeland" film theater in Tashkent (1938, architect A. Sidorov), the "Dinamo" stadium in Tbilisi (1934-1938, architect A. Kurdiani), the Government House in Yerevan (1926-1941, architect A. Tamanyan) (Fig. 17), and the blocks of residential houses in Ashgabat rebuilt after earquake of 1948 (Fig. 18), etc.

On city residents and newcomers the feeling of their dependence on Soviet society (unified "socialist content") was implemented by architectural measures, while local "nationalism", or, in the absence of real statehood, rather "folk character" express dependence



Fig. 17. The decor of the Palace of the Yerevan Government in Republic Square. R. Čepaitienè photo

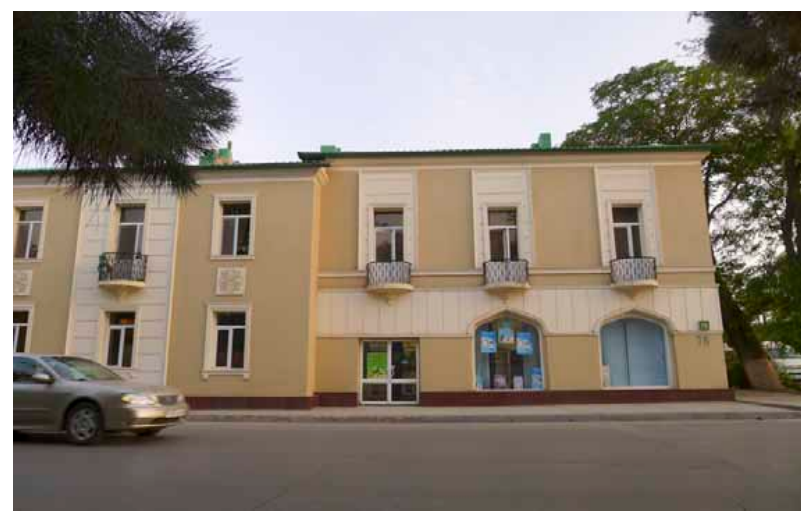

Fig. 18. Residential houses of Ashgabat, Turkmenistan. R. Čepaitienè photo 
on a concretely defined territory - a Soviet union or autonomous republic. In this way the strategy of the "localization of the national decor" became a kind of urban space marker, distinguishing one city from other similar ones. In the same way the use of elements of folk art in new construction was in line with the ideological goals and the fact that it supposedly reflected the unprivileged layers of society - "the people". Therefore, the architects were actively encouraged to rely on the experience of local folk architecture and aesthetic, and to try to integrate it into their project decisions.

Considering the certain perceived "emblem nature" in the distribution of plant motives, the hypothesis is raised that by using certain stylistic templates-metonymies (Lithuania-tulip (Fig. 19), Belarus - cornflower (Fig. 20), Moldova - grape (Fig. 21) Ukraine - sunflower (Fig. 22), Armenia - garnet, the Central Asian nations - cotton (Fig. 23), and so on) the Soviet regime visually and symbolically "marked" different ethno-cultural spaces. Of

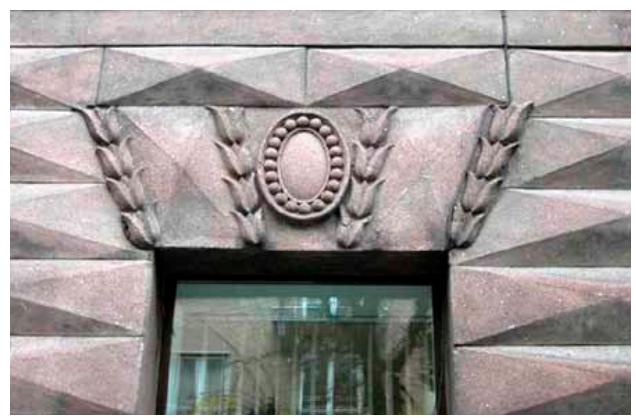

Fig. 19. The motive of tulips in the socialist realism architecture of Vilnius. R. Čepaitienè photo

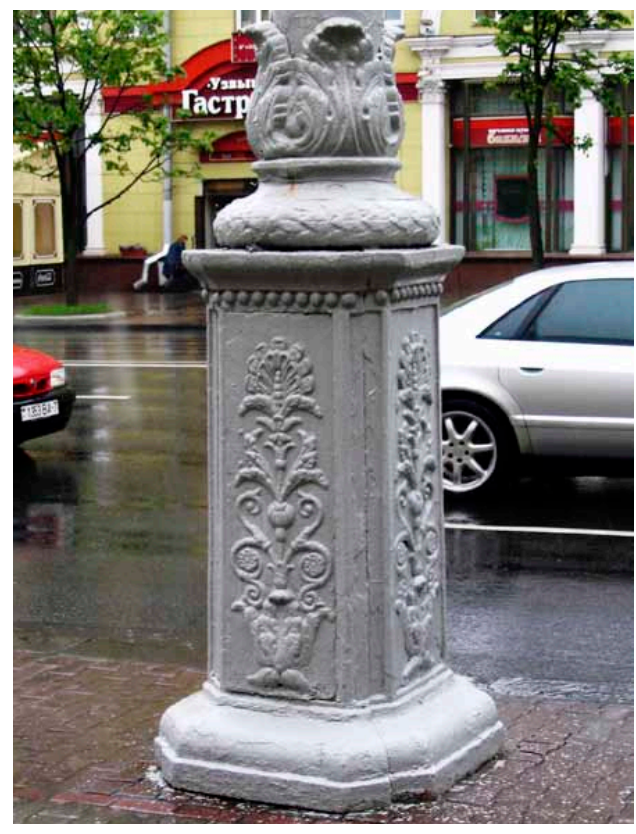

Fig. 20. The motive of cornflowers in the socialist realism architecture of Minsk. R. Čepaitienè photo course, this assumption still requires deeper and more thorough investigations, but the abundance of similar metonymies in the decor of the national pavilions in Moscow's All-Union People's Economic Achievement Exhibition (APEAE) complex (Nefedov 2014) could partially confirm this and especially in the sculptured composition of the "Friendship of Nations" fountain (Topuridze 1954), depicting the 16 Soviet republics "sisters" (Fig. 24). In such a way Soviet visual propaganda immediately solved two problems. On the one hand, the eclectically selected elements of classic styles dominating in the décor of the Stalinist buildings unified

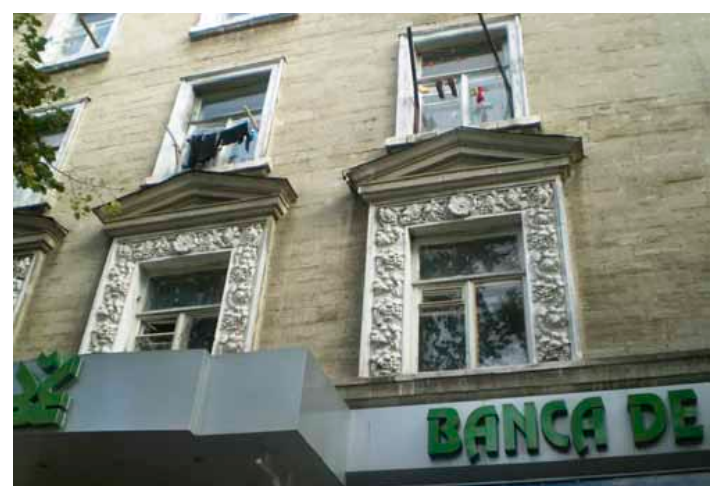

Fig. 21. The motive of grapes in socialist realism architecture of Chisinau. R. Čepaitienè photo

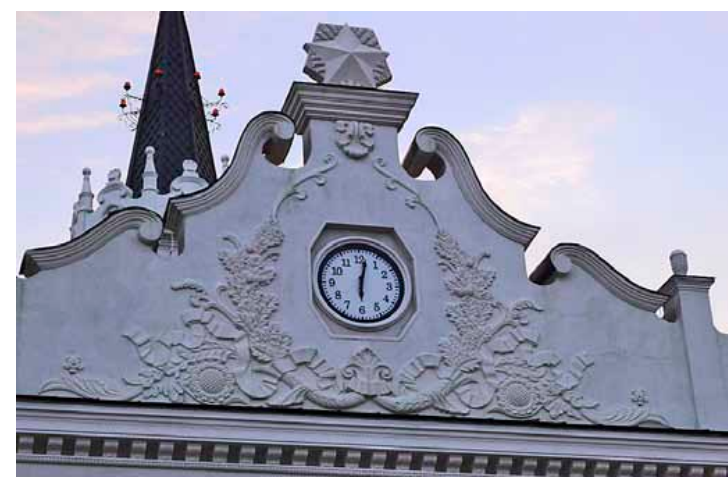

Fig. 22. The motive of sunflowers in the palace of the Charkov airport (the old corpus), Ukraine. R. Čepaitienè photo

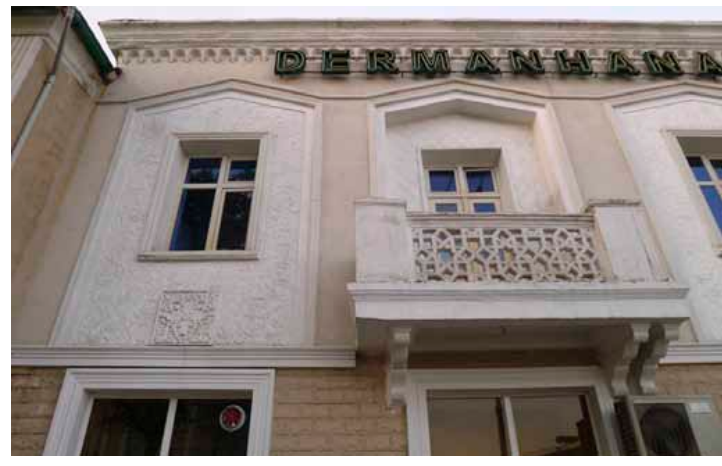

Fig. 23. Cotton and geometric motives in the socialist realism architecture of Ashgabat. R. Čepaitienè photo 


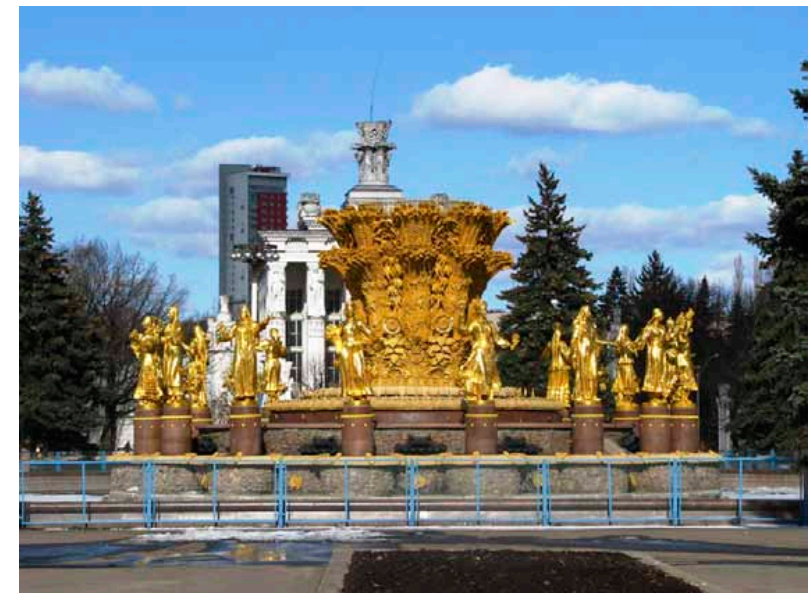

Fig. 24. The fountain of "The Friendship of Nations" in the complex of the exhibition of the accomplishments of the All-Union economy. Moscow, Russia. T. Korobova photo

it and embodied a unified imperial style, on the other hand, the sparse impurity of "national motives" allowed specific USSR nations to recognize in it features of "its characteristics", in this way evaluating it. This linking of two goals allowed Soviet ideology, not losing from sight the basic goal - the creation of the "Soviet man", at the same time demonstrating the apparent concern for the promotion of local national cultures.

\section{Conclusions}

In the Stalin era urban development and architectu$\mathrm{re}$, as well as any other types and forms of art, were subjected to serve totalitarian regime needs and state propaganda. The widely carried out transformations of cities also had to facilitate the process of the development of the unified Soviet man. Although in the Stalinist USSR the sole doctrine of socialist realism officially postulated its respect for "classical heritage", however, this was basically done by mechanically connecting selectively chosen historical stylistic and compositional forms for ideological purposes. Meanwhile, the authentic urban-architectural legacy frequently was being destroyed mercilessly, loosening space for the new neo-classical construction.

Totalitarian ideology especially sharpened the meaning of architecture as an effective instrument of social engineering: the planned environmental shifts had to promote the changes in the perception of people's habits, behavior and thinking. The new totalitarian thinking sought to create totally new forms of mediation between the government and the ruled and the institutions of interoperation and social control. And architecture also became one of these intermediaries. Interacting with propaganda and serving it totalitarian architecture was converted into a method of the total mobilization of individuals gathered into crowds and in the same way an arena for the political perfomances. With this one can explain its monumental and facade character, because the decorations create an effect only if they are visible from the outside and are not required to be majestic and beautiful from both sides or from the inside...

The processes of the vaccination of Soviet visual culture occurred simultaneously in all the cities of the USSR. In the logic of hierarchic, monochromatic and uncompromising Soviet culture a certain status of a systemic "brand" was given to the spaces of the capitals of the urban autonomous formations (the Soviet republics), placing them into the orbit of a harmoniously tuned totalitarian system. By urban, architectural and discursive methods and stereotyped national ornaments and symbols an ideological "circulation" was realized through "Stalin's Empire style" the archetype of the "Third Rome" penetrated into the form of the capitals of each USSR republic, and vice versa - all the national republics were symbolically illustrated in Moscow, in an unifying "knot of symbols" in the APEAE.

In the late Stalinist period in all the capitals of the Soviet republics one succeeded in forming the most important ideological accents, serving for the validation and establishment of Soviet political power and the installation of the scenario of collective memory, especially highlighting the storyboard of the "Great Patriotic War" in the landscapes of cities. Certain concessions to the architectural and folk traditions of the national republics should not obscure the fact that the apparent fostering of local cultures really meant the elimination of any signs of real statehood.

\section{References:}

Abensour, M. 1997. De la compasité. Architectures et régimes totalitaires. Paris: Sens and Tonka.

Alekseev, S. 1954. Arkhitekturnyi ornament. Moskva: Gosudarstvennoe izdatel'stvo literatury po stroitelstvu i arkhitekture.

Anacker, Sh. 2004. Geographies of power in Nazarbayev's Astana, Eurasian Geography and Economics 7: 515-533. http://dx.doi.org/10.2747/1538-7216.45.7.515

Andreev, E., et al. 1990. Opyt ocenki chislennosti naseleniya SSSR 1926-1941 g.g. (kratkiye rezultaty issledovaniya), Vestnik statistiki 7: 34-58.

Balyan, K. V. 2010. Sovetskaya arkhitektura Armenii: dve koncepcii razvitiya, Arkhitektura stalinskoy epokhi. Opyt istoricheskogo osmysleniya. Moskva: KomKnyga, 226-236.

Bogdanov, L. S. 1950. Riga, Tallinn, Vilnius. Rekonstrukciya istoricheski-slozhivshegosia ansamblia centra goroda: typescript of $\mathrm{PhD}$ theses. Moskva.

Bolshevik Culture. Experiment and Order in the Russian Revolution. 1985. A. Gleason, P. Kenez, R. Stites (Eds.). Bloomington: Indiana University Press. 
Borovoyi, R. 2004. Poslevoyennaya rekonstrukciya i vosstanovleniye Minska (Istoriya napisannaya i nenapisannaya). http://ais.by/story/206

Cadiot, J. 2007. Le laboratoire impérial. Russie-URSS 1870-1940. Paris: Éditions CNRS.

Cherniavskaya, J. 2010. Belorusy: ot „tuteyshyh" $k$ nacii. Minsk: FUA-inform.

Cherniavskaya, J. 2011. Samaya sovetskaya iz vseh sovetskih..., Neprikosnovennyi zapas 4(78). http://magazines.russ.ru/ $\mathrm{nz} / 2011 / 4 / \mathrm{ch} 10 . \mathrm{html}$

Choay, F. 1998. Pensées sur la ville; arts de la ville. La ville de l'age industriel. Le cycle haussmannien. M. Agulhon (Ed.). Paris: Editions du Seuil, 251-265.

Clark, K. 2011. Moscow, the Fourth Rome. Stalinism, Cosmopolitarianism and the Evolution of Soviet Culture, 1931-1941. Harvard University Press.

Cooke, C. 1993. Socialist Realist Architecture: Theory and Practice, Art of the Soviet: Painting, Sculpture and Architecture in a One Party State, 1917-1922. M. Callerne Bown, B. Taylor (Eds.). Manchester, New York: Manchester University Press.

Cope, B. 2008. Prizraki Marksa brodiat po Minsku po sledu Derrida, Belorusskyi format: nevidimaya realnost'. Vilnius, EHU Press, 498-521.

Čepaitienè, R. 2011. „Tarybinès sostinès“ konstravimas J. Stalino epochoje: Vilniaus ir Minsko atvejai. Nuo Basanavičiaus, Vytauto Didžiojo iki Molotovo ir Ribbentropo. Atminties ir atminimo kultūru transformacijos XX-XXI amžiuje. Vilnius: LII, 171-224.

Dobrenko, E. 2007. Politekonomiya socrealizma. Moskva: Novoe literaturnoe obozrenie.

Drèmaitè, M. 2009. Sovietmečio paveldas Vilniaus architektūroje: tarp lietuviškumo ir sovietiškumo, Naujasis Vilniaus perskaitymas: didieji Lietuvos istoriniai pasakojimai ir daugiakultūris miesto paveldas. Vilnius: VU.

Galinovskaya, Y. 2008. Semiosphera sovetskogo: k voprosu o semioticheskoj ekologii, O desovetizacii. Belarus, nachalo XXI veka: Materialy seminara-konferencii v g. Shilute (Litva) 20-24 avgusta 2007 g. Minsk: Centr socialnyh inovaciy, 52-60.

Gill, G. 2011. Symbols and Legitimacy in Soviet Politics. Cambridge University Press.

Golomstock, I. 1991. L'art totalitaire. Union Soviétique, III-e Reich, Italie fasciste, Chine. Paris: Editions Carré.

Ivanov, S. G. 2001. Arkhitektura v kul'turotvorchestve totalitarizma. Philosophsko-esteticheskiy analiz. Kiev: Stilos.

Khmelnickyi, D. 2006. Arkhitektura Stalina. Psikhologiya i stil’. Moskva: Progress-Tradiciya.

Khmelnickyi, D. 2009. Stalin i arkhitektura. http://ricolor.org/ history/rsv/good/arhi/

Khmelnickyi, D. 2007. Zodchiy Stalin. Moskva, Novoe literaturnoe obozrenie.

Kirychenka, V. 2006. Minsk. Gistarychny partret gorada 1953-1959. Minsk: Belarus.

Klinov, A. 2009. Gorad SONca. Vizualnaya paema pra Minsk. Photoalbom. Minsk: Logvinov.

Klinov, A. 2008. Malaya padarozhnaya knizhka pa Goradze SONca. Minsk: Logvinov.

Kosenkova, Y. L. 2010. Sredneaziatskyi gorod glazami arkhitektorov stalinskoy epokhi, Arkhitektura stalinskoy epokhi. Opyt istoricheskogo osmysleniya. Moskva: KomKnyga.
Kotkin, S. 1995. Magnetic Mountain. Stalinism as a Civilization. Berkeley: University of California Press.

Leggewie, C. 2010. Mūšio laukas - Europa, Europos istorijos: Rytu ir Vakary patirtis (sud. C. H. Fredreksson ir A. Samalavičius). Kultūros barai, 100-122.

Martin, T. 2001. The Affirmative Action Empire. Nations and Nationalism in the Soviet Union, 1923-1939. Cornell University Press.

Meerovich, M. G.; Konysheva, E. V.; Khmelnickyi, D. S. 2011. Kladbishche socgorodov: gradostroitel'naya politika v SSSR (1928-1932 g.g.). Moskva: ROSSPEN.

Meerovich, M. G. 2008. Nakazaniye zhil'em: zhilishchnaya politika v SSSR kak sredstvo upravleniya liud'mi (1917-1937). Moskva: ROSSPEN.

Milerius, N. 2008. Sinkhronizaciya i desinkhronizaciya nastoyashchego i proshlogo na sovetskom i postsovetskom prostranstvah. P.S. landshafty: optiki gorodskih issledovaniy. Vilnius: EHU, 37-62.

Nefedov, P. 2014. VSHV-39. http://www.chaskor.ru/article/vshv39_36238

Papernyi, V. 1996. Kul'tura Dva. Moskva: Novoe literaturnoe obozrenie.

Prot'ko, T. S. 2002. Stanovlenie sovetskoy totalitarnoy sistemy v Belarusi (1917-1941). Minsk: Tesey.

Rashin, A. G. 1960. Rost gorodskogo naseleniya v SSSR (1926-1959 g.g.), Istoricheskiye zapiski 66: 269-277.

Shamruk, A. 2007. Arkhitektura Belarusi XX - nachala XXI v.v. Minsk: Belarusskaya nauka.

Schlögel, K. 2008. Terror und Traum. Moskau 1937. München: Carl Hansen Verlag.

Snyder, T. 2003. The Reconstruction of Nations: Poland, Ukraine, Lithuania, Belarus, 1569-1999. Yale University Press.

Topuridze, K. 1954. Fontany Vsesoyuznoy sel'skokhoziyastvennoy vystavki, Arhitektura i stroitel'stvo Moskvy, no. 7. http:// www.bcxb.ru/doc/1954_ArchStrMos7.pdf

Tung, A. 2001. Preserving the World's Great Cities. New York: Three Rivers Press.

Vasykin, A. A.; Nazarenko, Y. I. 2009. Stalinskiye neboskreby: ot Dvorca Sovetov $k$ vysotnym zdaniyam. Moskva: Sputnik.

Volozhinskyi, V. G. 2007. Minsk. Staryi i novyi. Minsk: Kharvest.

Yaralov, Y. 1971. Nacional'noe i internacional'noe $v$ sovetskoy arkhitekture. Moskva: Stroyizdat.

Yusupov, V. A. 1992. Igra bez pravil: perepisi naseleniya SSSR v 30-e gody, Sovetskaya istoriya: problemy i uroki. Novosibirsk: Nauka, 149-167.

\section{RASA ČEPAITIENĖ}

PHD, senior researcher, Lithuanian Institute of History, Department of $20^{\text {th }}$ Century History, Professor, Vilnius University, Kražiu g. 5, LT-01108 Vilnius, Lithuania

E-mail: rasa.cepaitiene@if.vu.lt

Publications: author and editor of 5 monographs including Cultural Heritage in the Global World (2010, Russian and Lithuanian versions) and about 70 research papers published in Lithuania and abroad. Research interests: cultural heritage and collective memory theories, urban studies, Soviet culture and post-Soviet transformation. 